This item was submitted to Loughborough's Research Repository by the author.

Items in Figshare are protected by copyright, with all rights reserved, unless otherwise indicated.

\title{
On-line coupling of gel electrophoresis and inductively coupled plasma-mass spectrometry
}

\section{PLEASE CITE THE PUBLISHED VERSION}

http://dx.doi.org/10.1016/j.trac.2011.04.025

\section{PUBLISHER}

(C) Elsevier

\section{VERSION}

AM (Accepted Manuscript)

\section{PUBLISHER STATEMENT}

This work is made available according to the conditions of the Creative Commons Attribution-NonCommercialNoDerivatives 4.0 International (CC BY-NC-ND 4.0) licence. Full details of this licence are available at: https://creativecommons.org/licenses/by-nc-nd/4.0/

\section{LICENCE}

CC BY-NC-ND 4.0

\section{REPOSITORY RECORD}

Haider, Syed R., Barry L. Sharp, and Helen J. Reid. 2019. "On-line Coupling of Gel Electrophoresis and Inductively Coupled Plasma-mass Spectrometry”. figshare. https://hdl.handle.net/2134/19972. 
Online coupling of gel electrophoresis and inductively coupled plasma-mass spectrometry (GE-ICP-MS)- $A$ new trend in analytical chemistry

\author{
Syed R. Haider, Barry L. Sharp, Helen J. Reid* \\ Centre for Analytical Science, Department of Chemistry, Loughborough \\ University, Leicestershire, LE11 3TU, UK.
}

\begin{abstract}
The online coupling of gel electrophoresis with inductively coupled plasma mass spectrometry (GE-ICP-MS) is a powerful tool for the simultaneous separation, detection and quantification of bio-molecules and has been applied to the determination of phosphorus in DNA, phosphoproteins, phosphopeptides, gold in nano-particles, iron in metalloproteins, iodine in aerosols and cisplatin-oligonucleotide interactions. However, since the first report in 2005, relatively few papers have been published which perhaps reflects the lack of familiarity with the benefits of this promising methodology. So, here for the first time the applications of coupled GE-ICP-MS are critically reviewed, and an effort has been made to explore the advantages and limitations of the technique for various applications. Such scrutiny may be useful not only in the development of the technique but also in highlighting its potential in proteomics, genomics and metallomics.
\end{abstract}

Keywords: Agarose gel, buffer contamination, capillary electrophoresis (CE), elution buffer, high performance liquid chromatography (HPLC), inductively coupled plasma mass spectrometry (ICP-MS), online coupling, sodium dodecyl sulfate polyacrylamide gel electrophoresis (SDS-PAGE). 


\section{Introduction}

The rapid development of ICP-MS based techniques has opened new and exciting opportunities for the characterization of metal and non-metal associated bio-molecules [1]. However, there is still relatively little information about the role of the elements in biochemical processes which has prompted the development of the new field of metallomics. The combination of suitable separation techniques with ICP-MS detection has been a focus of research in recent years and several on-line and off-line techniques have been used for the separation and detection of bio-molecules such as immobilized metal affinity chromatography (IMAC) [2], reversed phase chromatography [3], size exclusion chromatography (SEC) [4], and capillary zone electrophoresis (CZE) [5] etc. However, for macromolecules, gel electrophoresis (GE) is still widely considered to be the definitive method of separation [6]. The combination of GE with detection methods such as: ICP-MS (GE-ICP-MS) [7] and Laser Ablation (LA) ICP-MS (GE-LA-ICP-MS) [8-12] has enabled gelbased methodologies to obtain more detailed information about the elemental composition of bio-molecules. The recently introduced on-line coupling of GE and ICP-MS is a very effective way of obtaining such information. It was first described by Brüchert and Bettmer in 2005 [13] for the determination of double stranded DNA fragments. More recently, it has been reported for several applications including: size characterization of gold nano particles [14], detection of iron in metalloproteins [15], determination of the degree of phosphorylation in casein [16], iodide and iodate determination in aerosols [17], detection of phosphorus in phosphoproteins [18], cisplatin-oligonuleotide interaction [19] and for the detection and quantification of phosphorus in plasmid DNA [20]. GE-ICP-MS could also be applied to other studies in metallomics, genomics and proteomics for the separation, detection and quantification of metals and non-metals in biological fluids such as serum, urine, saliva, cerebrospinal fluid, and drugs binding with DNA, RNA, and proteins etc. 
Coupled GE-ICP-MS enjoys a wide range of benefits over the conventional reverse phase (RP)-LC-ICP-MS technique [18] such as, the cost of the gel is much cheaper than the cost of the column used in LC-ICP-MS and is readily replaceable in case of damage; the flow rate is flexible ( $\mu \mathrm{L} \mathrm{min}^{-1}$ to $\mathrm{mL} \mathrm{min}^{-1}$ ) and conventional nebulizers are usually satisfactory; the non-volatile buffers used are more tolerable than the volatile buffers and organic solvents used in most RP-HPLC-ICP-MS separations and a wider range of sizes of biomolecules can be analyzed.

In micro $(\mu)$-LC-ICP-MS and capillary electrophoresis (CE)-ICP-MS, low flow rates limit the choice of the nebulizer and spray chamber; miniaturization may reduce robustness of the system [21]; $\mu$-LC may not be very useful in analyzing large bio-molecules and limited sensitivity and poor migration time are considered the major disadvantages of CE-ICP-MS [22]; similarly in some cases interaction of the analytes with the capillary wall may cause sample loss in CE [22]. However, in $\mu$-LC and CE smaller ID columns require low flow rates $\left(\mu \mathrm{L} \mathrm{min}^{-1}\right.$ or $\mathrm{nL} \mathrm{min}^{-1}$ ) which do provide positive environmental and economic benefits. The combination of CE with an ICP-MS detector potentially offers a tool of unique quality and enables both charged and neutral analytes to be separated in a single run [23-24]. Thus, a range of metalloproteins were determined using CE-ICP-MS [22], however, this trend has been decreasing slowly for the last few years and the technique has recently been more popular for non-metalloprotein analysis [22].

GE-ICP-MS also has some advantages over SEC-ICP-MS. The commercially available SEC columns are very expensive and the separating media, mostly made up of Sepharose or Superdex gels, cannot tolerate very high pressure. In GE-ICP-MS, however, the elution buffer is taken from a separate buffer reservoir or an embedded capillary inside the gel so that a high flow rate can easily pass through and does not damage the gel. To prevent drying out, SEC columns also need some extra care. The most important disadvantage of SEC-ICP-MS is the common use of very high buffer concentration in the 
mobile phase which may increase contaminant levels and thus increase the detection limit of the analytes. In the majority of SEC based analyses (such as serum protein analysis) the best separation is achieved by employing phosphate buffers which precludes the detection of $P$ as an analyte by ICPMS.

LA-ICP-MS is a powerful way of detecting analytes on solid substrates, however a comparison of GE-ICP-MS with GE-LA-ICP-MS shows that the former has several benefits. The clear cut benefit of GE-ICP-MS is that it is a single step analysis (GE-LA-ICP-MS requires two stages i.e. separation followed by detection) and it is much less expensive. The two step process may cause the loss of the analyte. Curling of the gel during LA analysis is also a severe issue, usually requiring transfer of the analytes onto a membrane which may cause further sample loss. Moreover, poor detection limit, loss of the weakly bound metals and staining and de-staining of the analytes (in some cases) further reduce its efficacy in comparison to GE-ICP-MS.

On the other hand, GE-ICP-MS also has several limitations and requires further work to overcome the problems. These limitations include: broader peaks; the possibility of fragmentation of the proteins in the gel [18]; contamination from the gel materials [18] and a time consuming separation in comparison with CE [25] and $\mu$-LC [26]. The separation of the analytes in GE, based on their isoelectric points ( $\mathrm{pl}$ values), can be a very slow process and can take several hours and thus it may not be well suited for GE-ICP-MS. For metalloproteins analysis by GE-ICP-MS, native-polyacrylamide gel electrophoresis (native-PAGE) is preferred to sodium dodecyl sulfate (SDSPAGE) as significant loss of non-covalently bound metals has been reported in SDS-PAGE [10, 27-29].

\section{GE separation strategies}

\subsection{Polyacrylamide gel electrophoresis for separation of proteins}


Polyacrylamide gel electrophoresis (PAGE), either one dimensional (1D) or two dimensional (2D), is routinely used for the separation of proteins in proteomic studies. In this technique polyacrylamide is used as a separating medium because it can withstand a high voltages, also it is highly thermostable, chemically inert and can be prepared with different pore sizes. Protein separation can be performed by using either SDS-PAGE or nativePAGE methods. Much has been written about the PAGE based separation methods and for further information the following references can be consulted $[17,30-31]$.

\subsection{Agarose gel electrophoresis for separation of DNA and RNA}

The basic reason for using agarose gels is the size of the DNA and RNA molecules. The pore sizes of the polyacrylamide gel, even with very low percentage gels, are not suitable for separating the DNA molecules because they are much larger in size; thus an agarose gel with different percentages is used to achieve the separation of DNA. Oligonucleotides can however be separated using PAGE. For more detailed information see [32-34].

\section{ICP-MS}

ICP-MS, when coupled to an appropriate separation or detection technique, such as Laser ablation (LA-ICP-MS) [35-38], is a very sensitive and selective detector for identifying and quantifying low and high molecular mass biomolecules. Quantitation performed by ICP-MS has several advantages: (a) ICP-MS can detect the analyte of interest at very low concentration, (b) mass balance can be established because the response is independent of structure and (c) calibration is straightforward usually being carried out with inorganic salts.

The major drawback of this technique is the interferences from the polyatomic ions formed from the atmospheric gases and argon in the plasma. Detailed information about ICP-MS can be obtained from several reviews [39-40]. 


\section{Coupled on-line GE-ICP-MS}

As described in the above paragraphs, gel electrophoresis is a unique and powerful way of separating large molecules, and its online coupling with ICPMS detection has opened the doors of huge opportunities to get more detailed information about bio-molecules. For example: the exact number of the tryptically digested phosphorylated peptides can be obtained quickly after their separation in the gel [18]. There is very little chance of losing the sample and much less analyte is required (micro to nano grams), as compared to offline separation performed in the gel, where a significant quantity of analytes is required for detection using a staining procedures.

\subsection{Some important components of the GE-ICP-MS system}

\subsubsection{Power supply for GE}

Electrical power for the separation is usually supplied by using one of the commercially available power supplies such as: PowerPac ${ }^{\mathrm{TM}} \mathrm{HC}$, high current power supply system (Bio-Rad Laboratories, Hemel Hampstead, UK); PowerPac $^{\mathrm{TM}} 3000$, with high voltage supply (Bio-Rad Laboratories, Munich, Germany); Phero-stab 300 power supply (Biotec-Fischer, Reiskirchen, Germany); or 250/250 power supply system (Desaga, Heidelberg, Germany)

\subsubsection{Separating medium}

Separation of the molecules is usually performed by casting the gel into glass tubes of various sizes and internal diameters. These gels are made up of acrylamide or agarose at different percentages depending on the molecular sizes of the molecules being separated. The diameter of the tubes and percentage of the gels significantly affect the separation. Smaller diameter tube gels provide sharper peaks with better resolution of the analytes [18]. Similarly, high percentage gels increase the elution time and slow down 
analyte migration to the ICP-MS and may cause broader peaks [18]. In SDSPAGE a stacking gel is usually cast on the top of the separating gel.

\subsubsection{Electrode buffer}

For the separation of the analytes in the gel, cathode and anode buffers are necessary. These electrode buffers are mostly prepared using Tris in combination with any other suitable chemical such as glycine, tricine, boric acid etc. Although it is not necessary to have both buffers with different concentrations and $\mathrm{pH}$, in some cases they can be different for example the original tricine-SDS-PAGE method has $100 \mathrm{mM}$ Tris-tricine and $0.1 \%(\mathrm{w} / \mathrm{v})$ SDS with $\mathrm{pH} 8.25$ at the cathode and $100 \mathrm{mM}$ Tris with $\mathrm{pH}$ of 8.9 at the anode $[29,41]$.

\subsubsection{Elution Buffer}

The elution buffer required to elute the analytes into the ICP-MS can be taken from the cathode or anode buffer chamber using a capillary connected directly with the ICP-MS nebulizer. However, it is equally possible to employ a separate buffer reservoir for this elution buffer.

\subsubsection{Dialysis membrane}

A dialysis membrane or a plug gel [15] is necessary to connect both electrode chambers in GE-ICP-MS. The dialysis membranes must have a lower molecular weight cut-off value than the molecular weight of the separating molecules, otherwise these molecules will pass through the membrane and will go into the lower buffer chamber instead of the ICP-MS. However, in some cases the molecules which are passed through the dialysis membrane can be sent to the ICP-MS using elution buffer [13]. These membranes are mostly made up of cellulose ester and are commercially available in a wide range of MW cut-off values. To obtain a high recovery of the separating 
molecules the size of the analytes should be at least double the cut-off sizes of the membranes.

\subsubsection{Connecting Tubings}

PEEK (polyetheretherketone) or Teflon tubes are typically used to connect the GE system with ICP-MS. In most cases one end of this tubing system connects with the elution buffer and the other with the ICP-MS nebulizer. The internal diameter of these tubings depends on the flow rate required. When electrode buffer is used as an elution buffer then a small diameter (e.g. 1-2 $\mathrm{mm}$ ) glass tube is set inside the gel for the continuous flow of the electrode/elution buffer [18].

\subsubsection{ICP-MS nebulizers and spray chamber}

Many different nebulizers, with various flow rates, are commercially available to nebulize the samples into the ICP. Various nebulizers and spray chambers are listed in Table 1. In contrast with the $\mu$ LC-ICP-MS and CE-ICP-MS, the GE-ICP-MS system imposes minimal restriction on nebulizer and spray chamber type and the selection is largely based on the flow rate.

\subsection{Instrumental configuration}

In GE-ICP-MS coupling, when self-aspiration is used, the gel electrophoretic apparatus is connected directly with the nebulizer of the ICP-MS using a smaller diameter tube (e.g. $0.05-0.5 \mathrm{~mm}$ ) but if a peristaltic pump is required then it connects with the ICP-MS nebulizer via peristaltic pump tubing. The gel tube, containing the gel for separation, is usually mounted between two buffer reservoirs, one acting as a cathode and the second acting as an anode. If the analytes are separated on the gel from cathode to anode then it is called anodal GE or if they are separated from anode to cathode then it is called cathodal GE [15]. An elution buffer is required to elute the analytes into the 
ICP-MS. This elution buffer may be one of the electrode buffers or a separate buffer reservoir can be employed. A peristaltic pump or self-aspiration methods can be used to transfer the analytes and buffers to the ICP-MS. Use of the peristaltic pump is sometimes necessary, especially if a detergent such as SDS is used, because SDS generates bubbles which may hinder the selfaspiration process. However, if possible self-aspiration should be adopted because reduced transport tube volume provides well resolved and better peak shapes than when a peristaltic pump is used [18].

A schematic diagram of GE-ICP-MS is shown in Fig. 1. with: (a) using the same buffer reservoir (Fig. 1a), and (b) using a separate buffer reservoir (Fig. 1b). In (a), the elution buffer is one of the electrode buffers. In (b) an additional buffer reservoir is placed in the system to elute the analytes to the ICP-MS instrument. Both instrumental methodologies are useful, however, set-up (a) has a few advantages over set-up (b) such as: most of the commercially available GE instruments contain only two reservoirs i.e., cathode and anode, hence there must be a detailed modification to use a separate buffer reservoir; pumping the buffer from a separate buffer reservoir builds up the pressure and thus displacement of the dialysis membrane may occur [18]. One disadvantage of using the same buffer reservoir system is that ICP-MS does not tolerate high buffer concentrations hence low buffer concentrations are required at the cathode or anode which may adversely affect the separation.

\subsection{Problems associated with GE-ICP-MS online coupling}

GE-ICP-MS is not without its problems, which has entailed further work to address a number of issues, as described below.

\subsubsection{Gel Material}


Gels made using polyacrylamide or agarose contain several potential contaminants and it is necessary to remove these from the gels before running the samples. Thus the suggested procedure is the electrophoretic washing of the blank gel prior to running the mixture of analytes [16]. However, longer washing may disturb the sieving properties of the gel, especially in PAGE and this may result in poorer resolution of analytes and hence fewer peaks might be observed than expected. To resolve this problem use of a low percentage gel of smaller diameter and shorter length is recommended because this reduces both the level of the contaminants and the washing time.

\subsubsection{Choice of the buffers}

An important issue in LC-ICP-MS hyphenated techniques is the optimization of the composition and flow rate of the mobile phase to the ICP-MS because ICP-MS does not tolerate high buffer or organic solvent concentrations. Organic buffers, which contain a high concentration of carbon have several adverse effects on ICP-MS such as: (a) a build up of carbon deposition leads to clogging of the interface cones and possibly the torch injector and, as a result, decreases the sensitivity of the ICP-MS instrument [42-43]; (b) a high level of carbon generates a number of polyatomic carbon based interferences e.g., $\mathrm{C}_{2}{ }^{2+}, \mathrm{CNH}^{+}, \mathrm{CO}_{2}{ }^{+}$and ${ }^{38} \mathrm{Ar}^{13} \mathrm{C}^{+}$which interfere with $\mathrm{Mg}^{+}, \mathrm{Al}^{+}, \mathrm{Ca}^{+}$and $\mathrm{V}^{+}$ respectively and (c) volatile buffers increase vapour loading and cause destabilization of the plasma. In order to use a high carbon concentration, additional optimization is necessary and for example the addition of oxygen to the nebulizer gas [42-43]. However, the addition of oxygen gas in the nebulizer flow may reduce cone life [1]. Consequently, use of a minimum concentration of non-volatile buffer is recommended in LC-ICP-MS analysis. Lobinski et al. [44] reported that up to $30 \mathrm{mM}$ Tris- $\mathrm{HCl}$ is well tolerated by ICPMS. However, using a very low concentration of the running buffer in GE significantly affects the separation efficiency of the gel and increases the elution time. To reduce the elution time very high currents need to be 
applied, but this may produce several negative effects such as an increased temperature in the system which can change the $\mathrm{pH}$, fragmentation of the separated proteins, and worsening of the detection limit by increasing the release of contaminants which start to elute from the gel material at elevated temperature [18, 31]. Similarly, using high buffer concentrations at the electrodes, or in the elution buffer, increases the background signal intensity and also worsens detection limits. For example: tricine-SDS-PAGE traditionally requires $100 \mathrm{mM}$ Tris, $100 \mathrm{mM}$ tricine and $0.1 \%(\mathrm{w} / \mathrm{v})$ SDS at the cathode and $100 \mathrm{mM}$ Tris only at the anode [29]. Recently, the tricine-SDSPAGE system has been simplified and a running buffer with $25 \mathrm{mM}$ Tristricine and $0.05 \%(\mathrm{w} / \mathrm{v})$ SDS (at both electrodes) was used successfully for coupled on-line GE-ICP-MS [18]. It was reported that with the high buffer concentration in the original tricine-SDS-PAGE method, the background signal intensity of ${ }^{31} \mathrm{P}$ was 2 to 3 times higher than in the modified method. The authors demonstrated very good separation with this modified system and interestingly decreasing the running buffer concentration did not result in any significant increase in the elution time.

\subsection{Applications}

Coupled GE-ICP-MS has been used for several applications and there follows a brief overview of these, discussing only the factors affecting the separation and detection of the analytes. The parameters applied in each of the GE-ICPMS couplings are listed in Table 2.

\subsubsection{Determination of dsDNA fragments}

GE-ICP-MS online coupling was first described for the separation and detection of ${ }^{31} \mathrm{P}$ in double-stranded DNA (dsDNA) fragments [13]. The sample was introduced into a sector-field ICP-MS instrument (Thermo Scientific, Bremen, Germany) using a separate buffer reservoir system. As shown in Fig. $2 \mathrm{a}$ and $\mathrm{b}$ separation could be improved by increasing the applied voltage 
$(300 \mathrm{~V})$ and well resolved peaks between 100-700 base pairs DNA were observed as compared to the separation at low voltage (250 V), however increasing the voltage produced adverse effects resulting in decreased peak heights and the absence of the peaks above 700 base pairs. The authors further described the high $\mathrm{pH}$ of the elution buffer as an important factor in achieving good resolution of the base pairs. Using this method the detection limit for phosphorus was $0.1 \mathrm{ng}$ for a $10 \mu \mathrm{L}$ injection volume which is equivalent to $\sim 1 \mathrm{ng}$ of DNA.

\subsection{2. $\alpha$ - and $\beta$-casein separation}

The separation and detection of phosphorus and sulphur in $\alpha$ - and $\beta$-casein was first performed by Helfrich et al. for the determination of the degree of phosphorylation using $10 \mathrm{pmol}$ of $\alpha$-casein and 55 pmol of $\beta$-casein (see Fig. 3a) [16]. A similar set-up of the GE-ICP-MS was applied here as described above [13]. A sample volume of $2-5 \mu \mathrm{L}$ was injected into the gel. The degree of phosphorylation was obtained as $9.1 \pm 0.5$ (number of maximum phosphorylation $=9$ ) for $\alpha$-casein and $4.9 \pm 0.3$ (number of maximum phosphorylation $=5$ ) for $\beta$-casein which shows very good agreement with the previously reported values [46]. The success of this separation and detection of ${ }^{31} \mathrm{P}$ was illustrated by an almost base line separation and an excellent peak shape; however sulphur showed high background signals. In coupled GEICP-MS, baseline separation of sulphur is very difficult due to the presence of sulphur in almost every chemical used in GE and also in ammonium persulfate (APS), an oxidising agent necessary for the polymerization of the PAGE gels. Sulphur background signals can be reduced by electrophoretic washing of the gels, however it is important to remember that this washing must not be prolonged as it can damage the gel and may result in poor separation and detection of the analytes. The detection limit of this separation was reported as 1 pmol for $\alpha$-casein and 1.2 pmol for $\beta$-casein. 
Using a modified tricine-SDS-PAGE system this $\alpha$ - and $\beta$-casein separation with detection of ${ }^{31} \mathrm{P}$ was also described by Haider et al. [18] using the same reservoir system and the same model of sector-field ICP-MS instrument. The injection volume was $10-\mu \mathrm{L}$ and very good signals were recorded for $1 \mathrm{fmol}$ concentration of each of $\alpha$ - and $\beta$-casein, as shown in Fig. 3b. $\alpha$-casein has 10 phosphorous atoms per molecule compared with 5 (Swiss-Prot) for $\beta$ casein and therefore the peak areas should be in the ration of $\sim 2: 1$. It was found however, that the $\beta$-casein was contaminated with several proteins including $\alpha$-casein, which enhanced the a-casein signal intensity (Fig. 3b). The resolution was sufficient, although with some tailing, and after elution of the protein the ${ }^{31} \mathrm{P}$ signals quickly reached the base line, which is an indication of a very low memory effect and very low background signals. The authors reported that ${ }^{31} \mathrm{P}$ buffer background signals of the modified tricineSDS-PAGE system [18] were 2 to 3 times lower than the original method indicating that decreasing the buffer concentration can significantly improve the detection limit. The P/S ratio was not calculated here as the use of SDS limits this system to identifying elements other than sulphur.

\subsubsection{Phosphopeptides separation}

Haider et al. have recently described the separation and detection of mono and tetra-phosphopeptides obtained from tryptic digest of $\beta$-casein as well as commercially available $\beta$-casein mono [T6 - (1P)] and tetra-phosphopeptide [T1 - 2(4P)] standards, using a similar GE-ICP-MS set-up to that previously described for $\alpha$ - and $\beta$-casein separation [18]. For the digest mixture initially a $10 \%(\mathrm{w} / \mathrm{v})$ polyacrylamide tube gel was employed, but good separation was not achieved. By increasing the gel percentage, mono- and tetraphosphopeptides were separated in a 15\% (w/v) tube gel (Fig. 4a), but with broader peak shape and significant tailing which was not removed by further increasing the percentage of acrylamide in the resolving gel. The authors reported that the mono and tetra-phosphopeptide peaks were not fully resolved due to the presence of several peptide impurities in the digest 
mixture. The low percentage tube gels were not able to separate these impurities and as a result all the peptides eluted as a single unresolved band. Confirmation of this was obtained by running the mixture of mono- and tetraphosphopeptide standards [T6 (1P)] and [T1-2 (4P)] separately (Fig. 4b), which were resolved in a $10.5 \%(\mathrm{w} / \mathrm{v})$ gel.

Several contributing factors to peak tailing in the electrophoretic peaks have been discussed in previous studies [47] including overloading of the analytes and low efficiency of the column. Hence a large number of unresolved ${ }^{31} \mathrm{P}$ peptide impurities were the major likely cause of peak tailing here. The main source of the phosphopeptide impurities could be mis-cleavages during the digestion [48] and $\alpha$-casein contamination [49], which was also digested with the $\beta$-casein. Slow mass transfer to the detector is also an important factor in peak broadening [18]. Thus by increasing the gel percentage, protein transportation to the ICP-MS slowed down causing broader peaks as shown in Fig. 4a.

Limits of detection of the phosphopeptides were 0.7 and $0.2 \mu \mathrm{M}$ for [T6 (1P)] and $[$ T1-2 (4P)] respectively using the criteria of three times the standard deviation of the blank. These correspond to 7 pmol and 2 pmol per $10 \mu \mathrm{L}$ sample of the mono and tetra-phosphopeptide solutions.

\subsubsection{Determination of iodide and iodate in aerosols}

The online coupling of GE and ICP-MS has also been described for the determination of iodide and iodate in liquid and aerosols [17]. The same instrumentation with minor modification was applied here as for the work reported in reference [13]. In this coupling separation and detection of low molecular weight ionic iodine species was performed. Although reducing the length of the gel shortened the elution time of the analytes, the authors suggested that gel length should not be decreased as it affects the separation efficiency of the low molecular weight analytes. To investigate the effect of 
varying the matrix on the sensitivity of the assay, all the iodine samples were prepared in sodium chloride solution. Interestingly, higher chloride concentration significantly suppressed the signal intensity and migration behaviour of the iodine species as a noticeable peak fronting and migration shift of iodide was observed at a chloride concentration of $1000 \mathrm{mg} \mathrm{L}^{-1}$ as compared to $100 \mathrm{mg} \mathrm{L}^{-1}$ whereas iodate migration was not affected. (Fig. 5a). These effects were further investigated using species-specific isotope dilution analysis (ssIDA), but the matrix effect was still observed as shown in Fig. 5b. Both separations showed almost a base line separation indicating the compatibility of the elution buffer and the gel with the system. The detection limit of both iodine species was determined as $0.08 \mu \mathrm{g} \mathrm{L}^{-1}\left(0.63 \mathrm{nmol} \mathrm{L}^{-1}\right)$ for the $5 \mu \mathrm{L}$ injection volume.

\subsubsection{Size characterization of gold nanoparticles}

For this application a GE system was coupled online with an ELAN 5000 (Perkin-Elmer SCIEX) ICP-MS system which was operated at 1300 Watt [14]. The analytes were separated on agarose gel and eluted into the ICP-MS using the elution buffer (of composition as detailed in Table 2) from a separate buffer reservoir. For the separation, the colloidal solution of the Au was treated with trisodium citrate solution and DL-mercapto succinic acid (MSA) separately with different ratios (for detailed procedure, see reference 14). The authors mentioned that because of the chosen ratio, the resulting sizes of the Au nano particles were 5 and $20 \mathrm{~nm}$ for citrate, and for MSA it was about 2 $\mathrm{nm}$. As shown in Fig. 6a the peaks of the Au nanoparticles synthesized with citrate were not well resolved and base line separation was not achieved due to significant peak tailing especially for the $5 \mathrm{~nm}$ particles. The Au nano particles synthesized with MSA showed nearly symmetrical peaks (Fig. 6b) and decreased the peak tailing which indicates that the separation depended on the chemical structure and surface composition of the nano particles. The authors further reported that the percentage of the agarose gel affected the 
retention time and the analytes eluted faster using low percentage agarose gel (Fig. 6a and b).

\subsubsection{Detection of iron in metalloproteins}

Another application of coupled GE-ICP-MS was demonstrated for the detection of the iron containing proteins (cytochrome $\mathrm{C}$, haemoglobin, transferrin and ferritin) using SDS-PAGE and native-PAGE [15]. This is also an example of a separate buffer reservoir system. Anodal and cathodal separation was performed in native-PAGE. A plug gel instead of the dialysis membrane was used to connect both electrodes. The separation of haemoglobin and cytochrome $\mathrm{C}$ is shown in Fig. 7a. The authors suggested that the correct quantification of iron could not be performed using SDS-PAGE as they found significant loss of iron from both haemoglobin and cytochrome $C$ in recovery studies. Anodal native-PAGE was carried out for the separation of transferrin and ferritin (Fig. 7b) and the authors found that recovery was poor for the ferritin in this system, however, the transferrin showed good agreement between the original and found value of the iron. The authors did not explain the reasons for the low recovery of iron in ferritin. The detection limits for Fe were estimated as 0.45 and $0.76 \mathrm{ng}$ for transferrin and ferritin respectively for a $35 \mu \mathrm{L}$ of injected volume. Similarly, for cathodal nativePAGE, cytochrome $C$ and haemoglobin were separated online (as shown in Fig. 7c). In contrast with SDS-PAGE, these analytes showed good recovery which indicates that good quantitative work can be performed using cathodal native-PAGE. However, haemoglobin showed slightly poorer recovery and the authors suggested this could be due to loss of protein or loss of the metal from the protein. For confirmation, the ratio of iron and sulphur signals after PAGE and after direct injection of the proteins was compared and both ratios showed good agreement which indicated that iron was not lost. Here, the detection limit for Fe for a $15 \mu \mathrm{L}$ sample injection volume was determined as $0.17 \mathrm{ng}$ in cytochrome $\mathrm{C}$ and $0.52 \mathrm{ng}$ in haemoglobin. 


\subsubsection{Oligonuleotide-cisplatin interaction}

In this application [19] the interaction of cisplatin with two different nucleotide sequences, one with two adjacent guanines (5'-TCCGGTCC-3') and one with the thymine and guanine sequence (5'-TCCTGTCC-3'), were investigated using GE coupled to isotope dilution ICP-MS using the GE-ICP-MS coupling system previously described [13]. Cisplatin was incubated for $3 \mathrm{~h}$ and $24 \mathrm{~h}$ with both nucleotides. The authors demonstrated that continuous reaction of cisplatin with oligonucleotides can be monitored using GE-ICP-MS and as shown in Fig. 8, cisplatin coordinated stepwise with oligonucleotides to form different adducts with increasing incubation time.

\subsubsection{DNA induced oxidation}

Recently another paper on GE-ICP-MS has been published for the detection and quantification of ${ }^{31} \mathrm{P}$ in the oxidative events in plasmid DNA [20]. This oxidative stress was induced in the samples by adding $\mathrm{Fe}^{2+}$ and $\mathrm{H}_{2} \mathrm{O}_{2}$ and ${ }^{31} \mathrm{P}$ was monitored before and after the addition of the enzyme [BamHI] (shown in Fig. 9). The system was the same as described in reference [13]. The detection limit achieved for this work was $100 \mathrm{pg}$ absolute $\mathrm{P}$ which is equivalent to $0.54 \mathrm{fmol}$ for the non-fragmented plasmid DNA.

\section{Concluding remarks}

In conclusion, a brief survey of GE-ICP-MS online coupling strategies is presented. Although to date this methodology has only been used in a few applications, here the focus was to explore the different aspects of this technique and critical review clearly suggests its flexibility and potential for wider application. It is important to note that incomplete separation of some analytes has been reported, which may be a limitation; however this methodology is still in its early stages and more work is required to develop this promising tool. Future interest in this technique should generate further 
publications and promote its development and it may eventually play a vital role in solving a range of biological problems.

\section{Acknowledgments}

We are thankful to Dr. Jörg Bettmer from the Department of Physical and Analytical Chemistry, University of Oviedo, Oviedo, Spain for providing us with the high quality original figures to publish in this review article. We are also thankful to the American Chemical Society (ACS), Royal Society of Chemistry (RSC) and Springer-Verlag for their permission to reproduce the published figures.

\section{References}

[1] J. Szpunar, R. Lobinski, Pure Appl. Chem. 71(1999) 899

[2] M. C. Posewitz, P. Tempst, Anal. Chem., 71(1999) 2883

[3] S. Hann, G. Koellensperger, C. Obinger, P. G. Furtmueller, G. Stingeder, J. Anal. At. Spectrom. 19 (2004) 74

[4] J. C. Moore, J. Polym. Sci. A2 (1964) 835

[5] J. Szpunar, R. Lobinski, A. Prange , Appl. Spectrosc. 57 (2003) 102.

[6] A. T. Andrews, Electrophoresis. Theory, Techniques, and Biochemical and Clinical Applications, 2nd ed. Oxford University Press: New York, 1988.

[7] V. L. Elliot, C. W. McLeod, P. S. Marshall, Anal. Bioanal. Chem. 383 (2005) 416.

[8] P. S. Marshall, O. Heudi, S. Bains, H. N. Freeman, F. Abou-Shakra, K. Reardon, Analyst 127 (2002) 459.

[9] M. Wind, I. Feldmann, N. Jakubowski, W. D. Lehmann, Electrophoresis 7 (2003) 1276.

[10] A. Raab, B. Pioselli, C. Munro, J. Thomas-Oates, J. Feldmann, Electrophoresis 30 (2009) 303.

[11] G. Ballihaut, C. Pécheyran, S. Mounicou, H. Preud'homme, R. Grimaud, R. Lobinski, Trends Anal. Chem. 26 (2007) 183. 
[12] G. Ballihaut, F. Claverie, C. Pécheyran, S. Mounicou, R. Grimaud, R. Lobinski, Anal. Chem. 79 (2007) 6874.

[13] W. Brüchert, J. Bettmer, Anal. Chem. 77 (2005) 5072.

[14] A. Helfrich, W. Brüchert, J. Bettmer, J. Anal. At. Spectrom. 21 (2006) 431

[15] M. G. Anorbe, J. Messerschmidt, I. Feldmann, N. Jakubowski, J. Anal. At. Spectrom. 22 (2007) 917.

[16] A. Helfrich, J. Bettmer, J. Anal. At. Spectrom. 22 (2007) 1296

[17] W. Brüchert, A. Helfrich, N. Zinn, T. Klimach, M. Breckheimer, H. Chen, S. Lai, T. Hoffmann, J. Bettmer, Anal. Chem. 79 (2007) 1714.

[18] S. R. Haider, H. J. Reid, B. L. Sharp, Anal. Bioanal. Chem. 397 (2010) 655.

[19] W. Brüchert, R. Krüger, A. Tholey, M. Montes-Bayón, J. Bettmer, Electrophoresis. 29 (2008) 1451.

[20] L. L. Fernández, M. Montes-Bayón, E. B. González, L. M. Sierra, A. Sanz-Medel, J. Bettmer, J. Anal. At. Spectrom. 26 (2011) 195.

[21] C. Czerwenka, M. Lämmerhofer, W. Lindner J. Pharm. Biomed. Anal 30 (2003) 1789.

[22] A. Prange, D. Pröfrock, Anal. Bioanal. Chem. 383 (2005) 372

[23] Xue-Bo Yin, Y. Li, Xiu-Ping Yan, Trends Anal. Chem. 27 (2008) 554.

[24] K. A. Taylor, B. L. Sharp, D. J. Lewis and H. M. Crews, J. Anal. At. Spectrom., 13 (1998), 1095.

[25] L. Bendahl, B. Gammelgaard, J. Anal. At. Spectrom. 19 (2004) 143

[26] M. Wind, M. Edler, N. Jakubowski, M. Linscheid, H. Wesch, W. D. Lehmann Anal Chem 73 (2001) 29

[27] M. S. Jiménez, M. T. Gomez, L. Rodriguez, L. Martinez, J. R. Castillo, Anal. Bioanal. Chem. 393 (2009) 699.

[28] M. S. Jiménez, L. Rodriguez, M.T. Gomez, J.R. Castillo, Talanta 81 (2010) 241.

[29] A. Polatajko, M. Azzolini, I. Feldmann, T. Stuezel, N. Jakubowski, J. Anal. At. Spectrom. 22 (2007) 878

[30] H. Schägger, Nature Protocols, 1 (2006) 16. 
[31] B. D. Hames (Editor), Gel Electrophoresis of Proteins Oxford University Press, New York, 1998.

[32] J. R. Brody, S. E. Kern, Anal. Biochem. 333 (2004) 1.

[33] N. J. Rampino, A. Chrambach, J. Chromatogr. A., 596 (1992) 141.

[34] J. M. Ordovas: in J. M. Ordovas (Editor), Methods in Molecular Biology: Lipoproteins protocols, Humana Press, New Jersey, USA, 1998, pp 3542.

[35] C. O'Connor, M. R. Landon and B. L. Sharp, J. Anal. At. Spectrom. 22 (2007) 273

[36] C. O'Connor, B. L. Sharp, P. Evans, J. Anal. At. Spectrom. 21 (2006) 556.

[37] J. S. Becker, D. Salber, Trends Anal. Chem. 29 (2010) 966.

[38] C. C. Chéry, D. Günther, R. Cornelis, F. Vanhaecke, L. Moens, Electrophoresis 24 (2003) 3305

[39] A. Sanz-Medel, M. Montes-Bayon, M. R. Fernandez de la Campa, J. R. Encinar, J. Bettmer, Anal. Bioanal. Chem. 390 (2008) 3.

[40] J. Bettmer, M. Montes-Bayon, J. R. Encinar, M. L. Fernandez-Sanchez, M. R. Fernandez de la Campa, A. Sanz-Medel, J. Proteom. 72 (2009) 989.

[41] H. Schagger, G. V. Jagow, Anal. Biochem. 166 (1987) 368.

[42] K. L. Sutton, J. A. Caruso, J. Chromatogr. 856 (1999) 243.

[43] E. G. Yanes, N. J. Miller-Ihli, Spectrochimica Acta Part B 60 (2005) 555.

[44] R. Lobinski, H. Chassaigne, J. Szpunar, Talanta 46 (1998) 271.

[45] M. Wind, H. Wesch, W. D. Lehmann, Anal. Chem. 73 (2001) 3006.

[46] D. R. Bandura, V. I. Baranov, S. D. Tanner, Anal. Chem. 74 (2002) 1497.

[47] T. Fornstedt, G. Zhong, G. Guiochon, J. Chromatogr. A 741(1996) 1.

[48] M. R. Larsen, T. E. Thingholm, O. N. Jensen, P. Roepstorff, T. J. Jorgensen, Mol. Cell Proteomics 4 (2005) 873

[49] D. Pröfrock, A. Prange, J. Chromatogr. A 1216 (2009) 6706. 
Table 1: Some of the commercially available widely used nebulizers and spray chambers

\section{Nebulizers}

- PFA micro-flow nebulizer (Elemental Scientific, Omaha, USA) with flow rate range of 20 to $400 \mu \mathrm{L} \mathrm{min}{ }^{-1}$

- PFA-ST nebulizer (Elemental Scientific, Omaha, USA) with selfaspiration rate of 20 to $700 \mu \mathrm{L} \mathrm{\textrm {min } ^ { - 1 }}$

- Micromist nebulizer (Glass Expansion, Victoria, Australia), with flow rate range of 0.05 to $0.4 \mathrm{~mL} \mathrm{~min}^{-1}$

- U5000AT ${ }^{+}$ultrasonic nebulizer (CETAC Technologies, Omaha, Nebraska, USA) with uptake rate of 0.5 to $2.5 \mathrm{~mL} \mathrm{~min}^{-1}$

- Aspire $^{T M}$ PFA Microconcentric Nebulizer (CETAC Technologies, Omaha, Nebraska, USA) with flow rate of 50 to $400 \mu \mathrm{L} \mathrm{min}{ }^{-1}$

- DS-5 Microflow concentric nebulizer (CETAC Technologies, Omaha, Nebraska, USA) for the flow of 3 to $10 \mu \mathrm{L} \mathrm{min}{ }^{-1}$

\section{Spray Chambers}

- Quartz and PFA cyclonic spray chamber (Elemental Scientific Omaha, USA) with higher aerosol transport efficiency.

- Scott type spray chamber (Glass Expansion Victoria, Australia)

- Cinnabar spray chamber with helix (Glass Expansion, Victoria, Australia)

- Tracey PFA44 spray chamber with helix (Glass Expansion, Victoria, Australia)

- Stable sample introduction (SSI) dual Quartz cyclonic spray chamber (Elemental Scientifc, Omaha, USA)

- Laser ablation dual quartz cyclonic spray chamber (Elemental Scientific, Omaha, USA) 
Table 2: Parameters used in GE-ICP-MS online couplings

\begin{tabular}{|c|c|c|c|c|c|c|c|c|c|}
\hline ICP-MS System & Nebulizer & $\begin{array}{l}\text { Spray } \\
\text { Chamber }\end{array}$ & Gel Material & $\begin{array}{l}\text { Injection } \\
\text { Volume }\end{array}$ & $\begin{array}{l}\text { Elution } \\
\text { Buffer }\end{array}$ & $\begin{array}{l}\text { Flow } \\
\text { Rate }\end{array}$ & Analytes & $\begin{array}{l}\text { Internal } \\
\text { Standard }\end{array}$ & Reference \\
\hline $\begin{array}{l}\text { Element 2, Thermo Scientific, } \\
\text { Bremen, Germany operated at } \\
1300 \text { Watt }\end{array}$ & $\begin{array}{l}\text { PFA } \mu \text {-Flow, } \\
\text { Elemental Scientific, } \\
\text { Omaha, NE }\end{array}$ & $\begin{array}{l}\text { Scott Type } \\
\text { Glass Expansion } \\
\text { Pocasset, MA }\end{array}$ & $\begin{array}{l}\text { 1.8\% Agarose, } \\
\text { Polyacrylamide }\end{array}$ & $5-50 \mu \mathrm{L}$ & $\begin{array}{l}0.09 \mathrm{~mol} \mathrm{~L}^{-1} \mathrm{TBE} \\
(\mathrm{pH} 8.0) \\
10 \mu \mathrm{g} \mathrm{L}^{-1} \mathrm{Rh}\end{array}$ & $100 \mu \mathrm{L} \min ^{-1}$ & ${ }^{31} \mathrm{P}$ & ${ }^{103} \mathrm{Rh}$ & 13 \\
\hline $\begin{array}{l}\text { Element 2, Thermo Scientific, } \\
\text { Bremen, Germany, operated at } \\
1300 \text { Watt }\end{array}$ & $\begin{array}{l}\text { Micromist } \\
\text { AHF, Feuerbacher } \\
\text { Tubingen, Germany }\end{array}$ & $\begin{array}{l}\text { Scott-Type } \\
\text { AHF, Feuerbacher } \\
\text { Tubingen, Germany }\end{array}$ & $5 \%$ Agarose & $2-5 \mu \mathrm{L}$ & $\begin{array}{l}10 \mathrm{mmol} \mathrm{L}^{-1} \text { Tris- } \\
\text { borate, } 5 \mathrm{mmol}^{\mathrm{NaCl}} \\
\left(\mathrm{pH} \mathrm{9.1)}, 10 \mu \mathrm{Lg} \mathrm{L}^{-1} \mathrm{Rh}\right.\end{array}$ & $100 \mu \mathrm{L} \min ^{-1}$ & ${ }^{31} \mathrm{P},{ }^{32} \mathrm{~S}$ & ${ }^{103} \mathrm{Rh}$ & 16 \\
\hline $\begin{array}{l}\text { Element 2XR, Thermo Scientific, } \\
\text { Bremen, Germany, operated at } \\
1300 \text { Watt }\end{array}$ & $\begin{array}{l}\text { PFA } \mu \text {-Flow, } \\
\text { Elemental Scientific, } \\
\text { Omaha, NE }\end{array}$ & $\begin{array}{l}\text { Cyclonic, } \\
\text { Glass Expansion } \\
\text { Victoria, Australia }\end{array}$ & Polyacrylamide & $10 \mu \mathrm{L}$ & $\begin{array}{l}25 \mathrm{mM} \text { Tris- } \\
\text { tricine }(\mathrm{pH} 8.2) \\
0.05 \%(\mathrm{w} / \mathrm{v}) \text { SDS }\end{array}$ & $130 \mu \mathrm{L} \min ^{-1}$ & ${ }^{31} \mathrm{P}$ & - & 18 \\
\hline $\begin{array}{l}\text { Element 2, Thermo Scientific, } \\
\text { Bremen, Germany, operated at } \\
1300 \text { Watt }\end{array}$ & $\begin{array}{l}\text { Micro-Flow, } \\
\text { AHF, Feuerbacher } \\
\text { Tubingen, Germany }\end{array}$ & $\begin{array}{l}\text { Scott-Type } \\
\text { AHF, Feuerbacher } \\
\text { Tubingen, Germany }\end{array}$ & Agarose & $2-20 \mu \mathrm{L}$ & $\begin{array}{l}0.05 \mathrm{~mol} \mathrm{~L}^{-1} \text { boric- } \\
\text { acid }\left(\mathrm{pH}^{-1} .0\right) \\
10 \mu \mathrm{L} \mathrm{L}^{-1} \mathrm{Te}\end{array}$ & $100 \mu \mathrm{L} \min ^{-1}$ & ${ }^{127} \mathrm{I},{ }^{129} \mathrm{I}$ & ${ }^{126} \mathrm{Te},{ }^{131} \mathrm{Xe}$ & 17 \\
\hline $\begin{array}{l}\text { ELAN } 5000 \text { (Perkin-Elmer } \\
\text { SCIEX, Uberlingen, Germany), } \\
\text { Operated at } 1300 \text { Watt }\end{array}$ & $\begin{array}{l}\text { Cross-Flow } \\
\text { AHF, Feuerbacher } \\
\text { Tubingen, Germany }\end{array}$ & $\begin{array}{l}\text { Scott-Type } \\
\text { AHF, Feuerbacher } \\
\text { Tubingen, Germany }\end{array}$ & $2 \%$ Agarose & $1 \mu \mathrm{L}$ & $\begin{array}{l}10 \mathrm{mmol} \mathrm{L}^{-1} \mathrm{SDS} \\
1 \mathrm{mmol} \mathrm{L}^{-1} \mathrm{NaH}_{2} \mathrm{PO}_{4} \\
1 \mathrm{mmol} \mathrm{L}^{-1} \mathrm{Na}_{2} \mathrm{HPO}_{4} \\
10-\mu \mathrm{g} \mathrm{g} \\
\end{array}$ & $300 \mu \mathrm{L} \min ^{-1}$ & ${ }^{197} \mathrm{Au}$ & ${ }^{103} \mathrm{Rh}$ & 14 \\
\hline $\begin{array}{l}\text { Element 2, Thermo Scientific } \\
\text { Bremen, Germany, operated at } \\
1300 \text { Watt }\end{array}$ & $\begin{array}{l}\text { Micromist } \\
\text { AHF, Feuerbacher } \\
\text { Tubingen, Germany }\end{array}$ & $\begin{array}{l}\text { Cyclonic, } \\
\text { Cinnabar, Glass } \\
\text { Expansion, Melbourne, } \\
\text { Australia }\end{array}$ & Polyacrylamide & $\begin{array}{l}15 \text { and } \\
35 \mu \mathrm{L}\end{array}$ & $\begin{array}{l}0.02 \mathrm{~mol} \mathrm{~L}^{-1} \text { Tris } \\
\mathrm{pH}(8.0)\end{array}$ & $140 \mu \mathrm{L} \min ^{-1}$ & $\begin{array}{l}{ }^{32} \mathrm{~S},{ }^{56} \mathrm{Fe}, \\
{ }^{79} \mathrm{Br}\end{array}$ & - & 15 \\
\hline $\begin{array}{l}\text { Element 2, Thermo Scientific } \\
\text { Bremen, Germany, operated at } \\
1300 \text { Watt }\end{array}$ & $\begin{array}{l}\text { Micromist } \\
\text { AHF, Feuerbacher } \\
\text { Tubingen, Germany }\end{array}$ & $\begin{array}{l}\text { Scott Type, } \\
\text { AHF, Feuerbacher } \\
\text { Tubingen, Germany }\end{array}$ & $4 \%$ Agarose & $2 \mu \mathrm{L}$ & $\begin{array}{l}0.05 \mathrm{~mol} \mathrm{~L}^{-1} \\
\text { ammonium } \\
\text { acetate } \\
4-\mu \mathrm{L} \mathrm{L}^{-1} \mathrm{Rh}\end{array}$ & $100 \mu \mathrm{L} \min ^{-1}$ & ${ }^{31} \mathrm{P},{ }^{195} \mathrm{Pt}$ & ${ }^{103} \mathrm{Rh}$ & 19 \\
\hline $\begin{array}{l}\text { Element 2, Thermo Scientific } \\
\text { Bremen, Germany, Operated at } \\
1350 \text { Watt }\end{array}$ & $\begin{array}{l}\text { Concentric } \\
\text { (CETAC, Omaha } \\
\text { Nebraska, USA) }\end{array}$ & $\begin{array}{l}\text { Not mentioned } \\
\text { in original paper }\end{array}$ & $0.8 \%$ Agarose & $10 \mu \mathrm{L}$ & $\begin{array}{l}50 \mathrm{mmol} \mathrm{L}^{-1} \\
\text { ammonium } \\
\text { acetate }\end{array}$ & $700 \mu \mathrm{L} \min ^{-1}$ & ${ }^{31} \mathrm{P}$ & ${ }^{103} \mathrm{Rh}$ & 20 \\
\hline
\end{tabular}


Fig.1

(a)

Upper Buffer Chamber

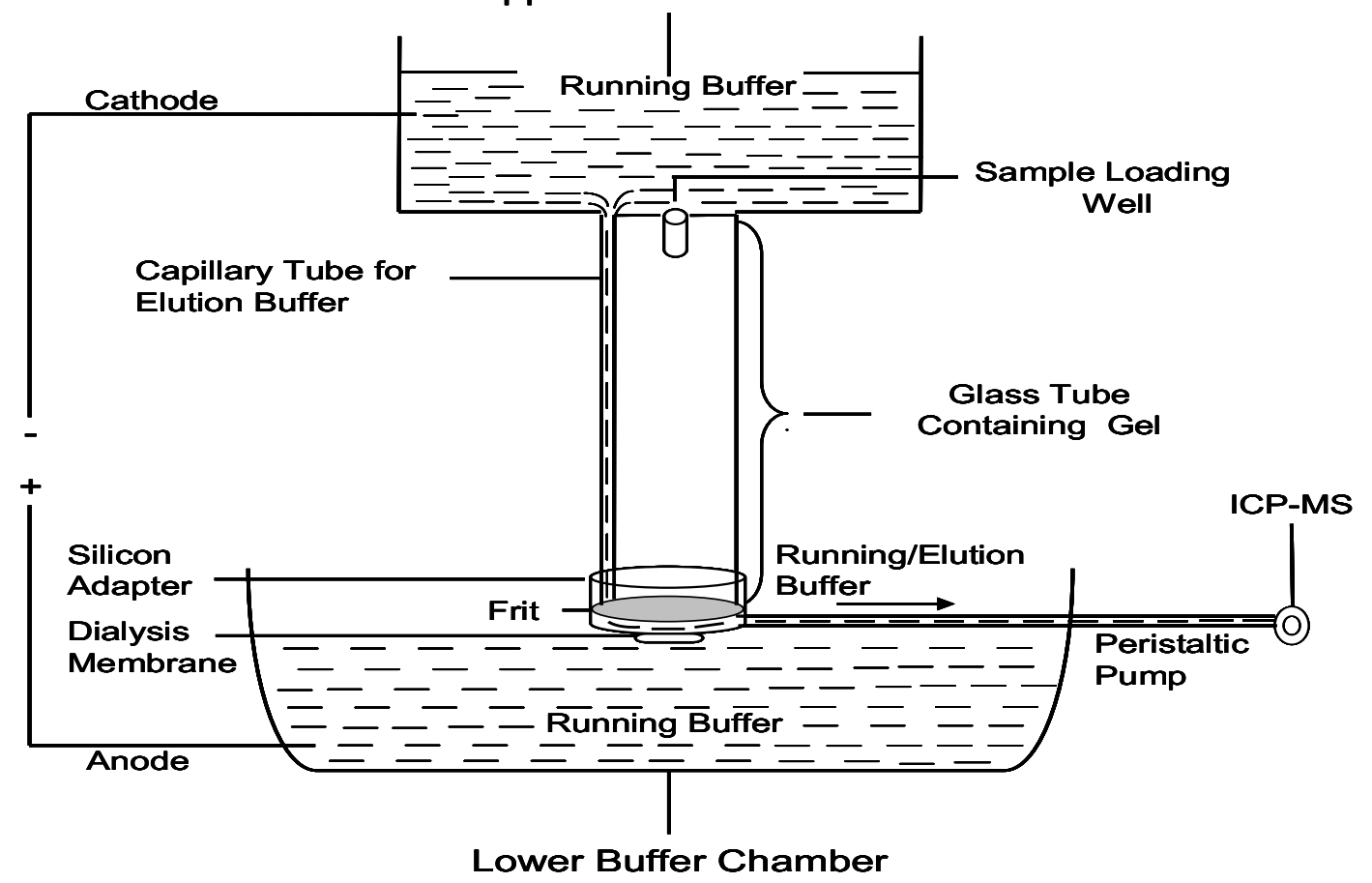

(b)

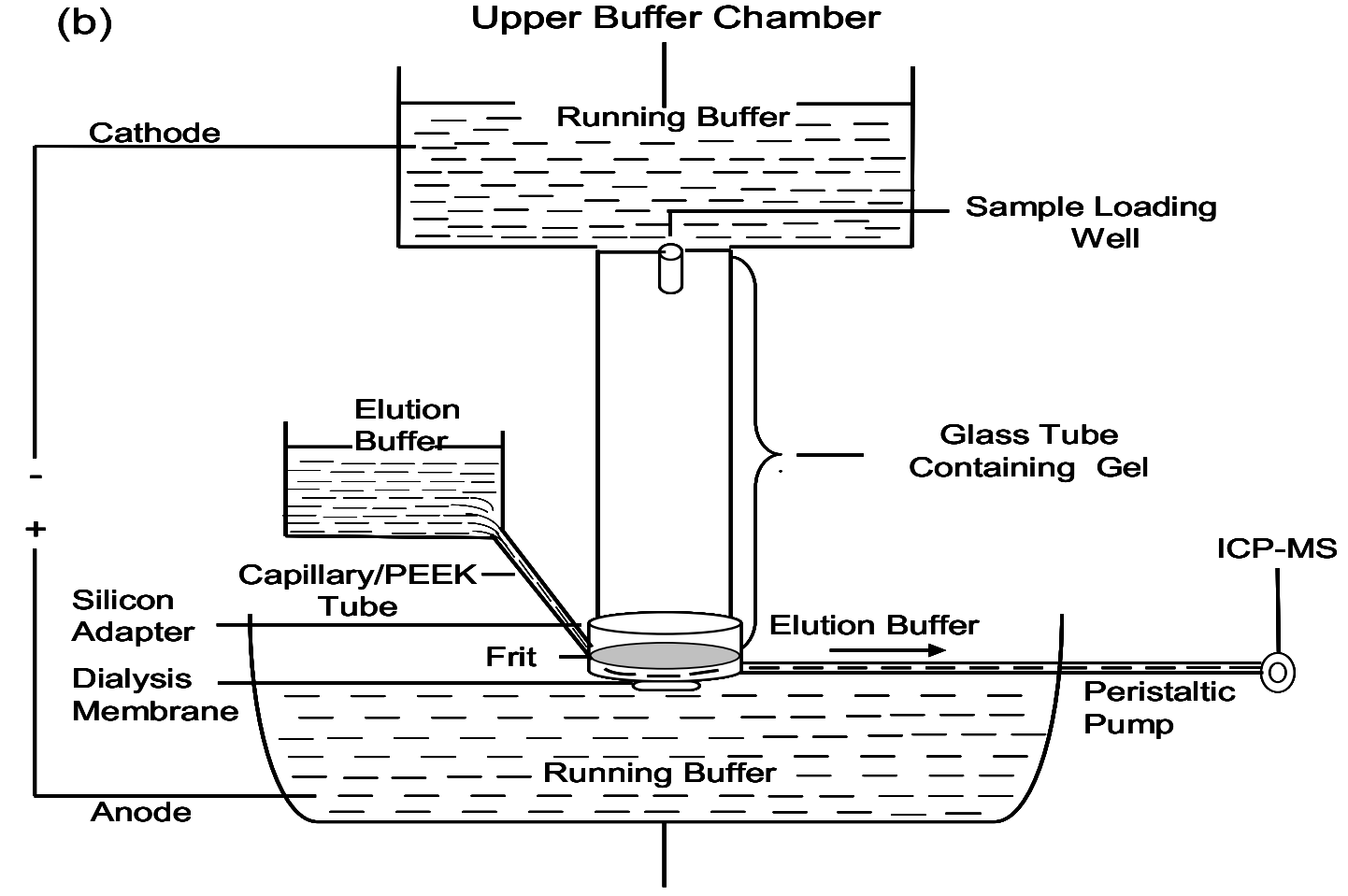

Lower Buffer Chamber 
Fig. 2

(a)

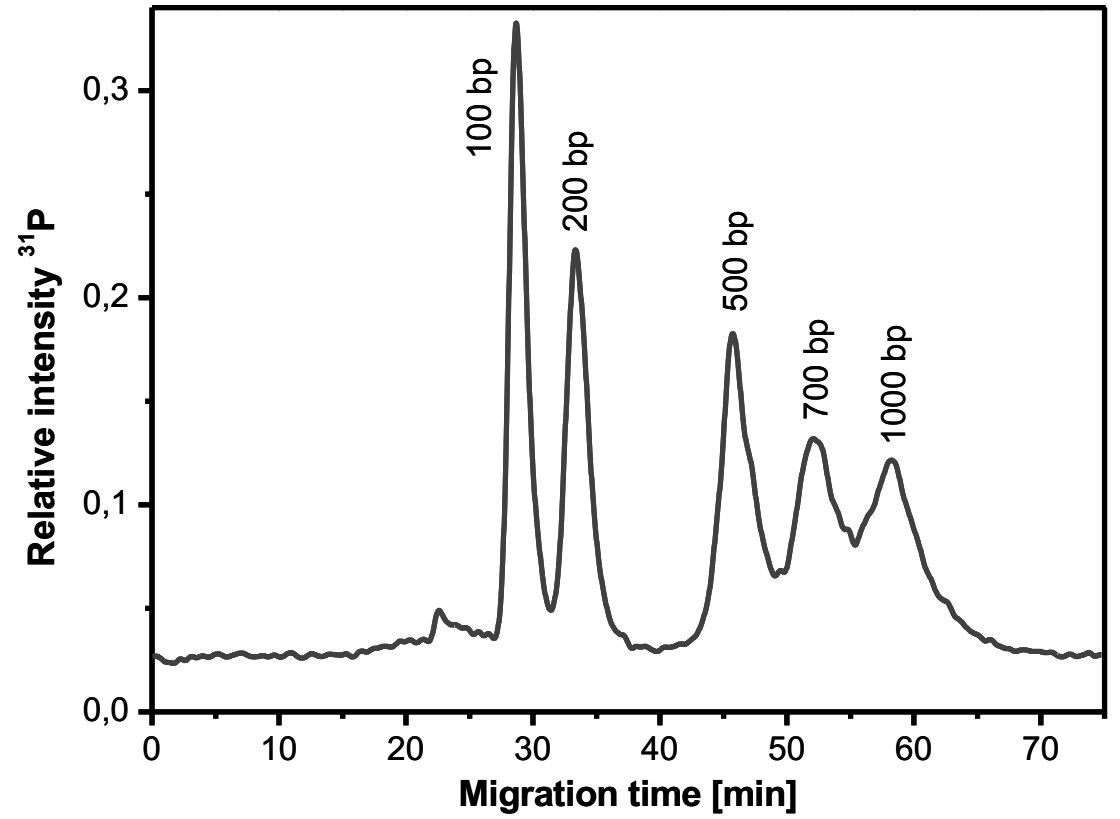

(b)

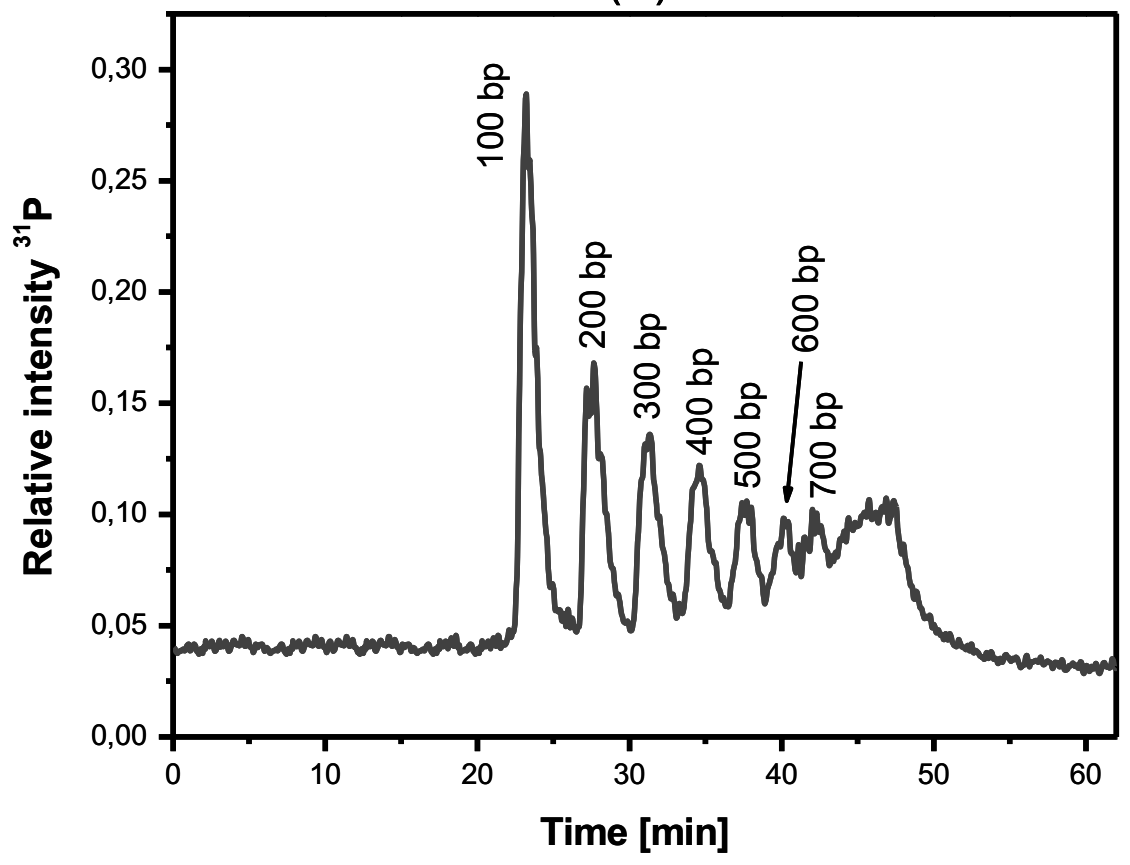


Fig. 3

(a)

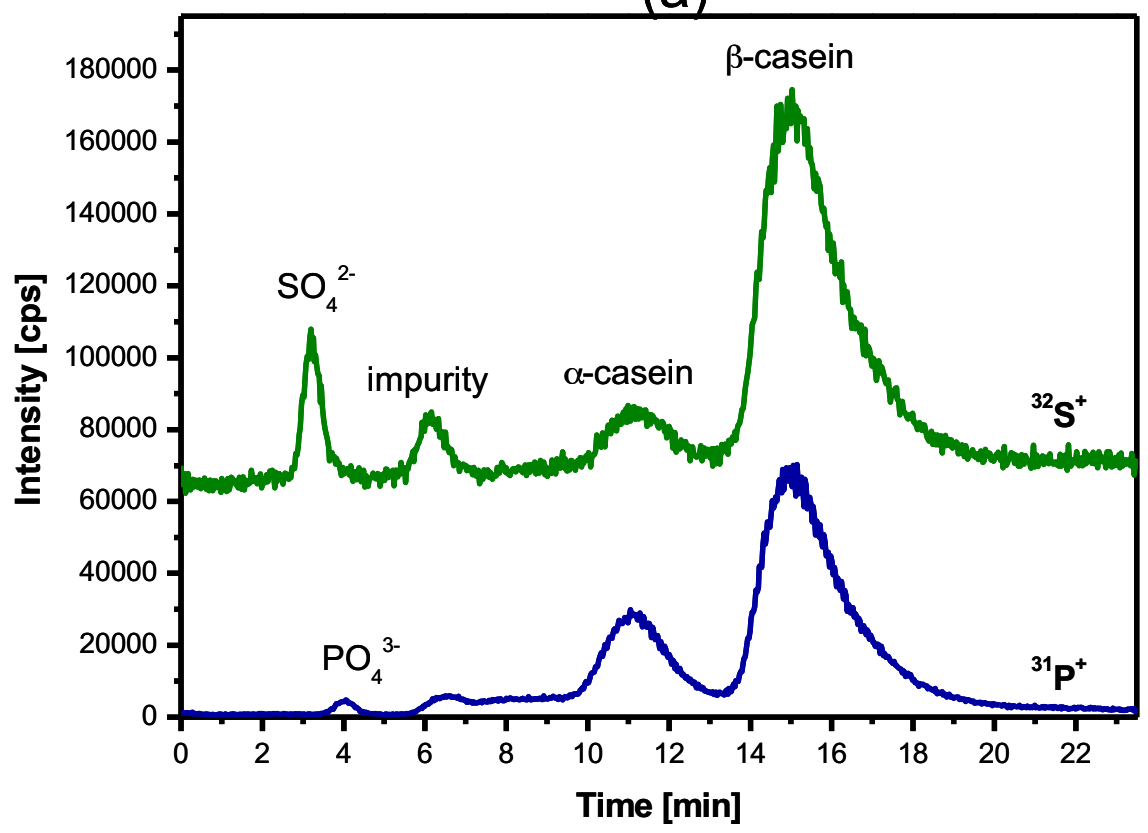

(b)

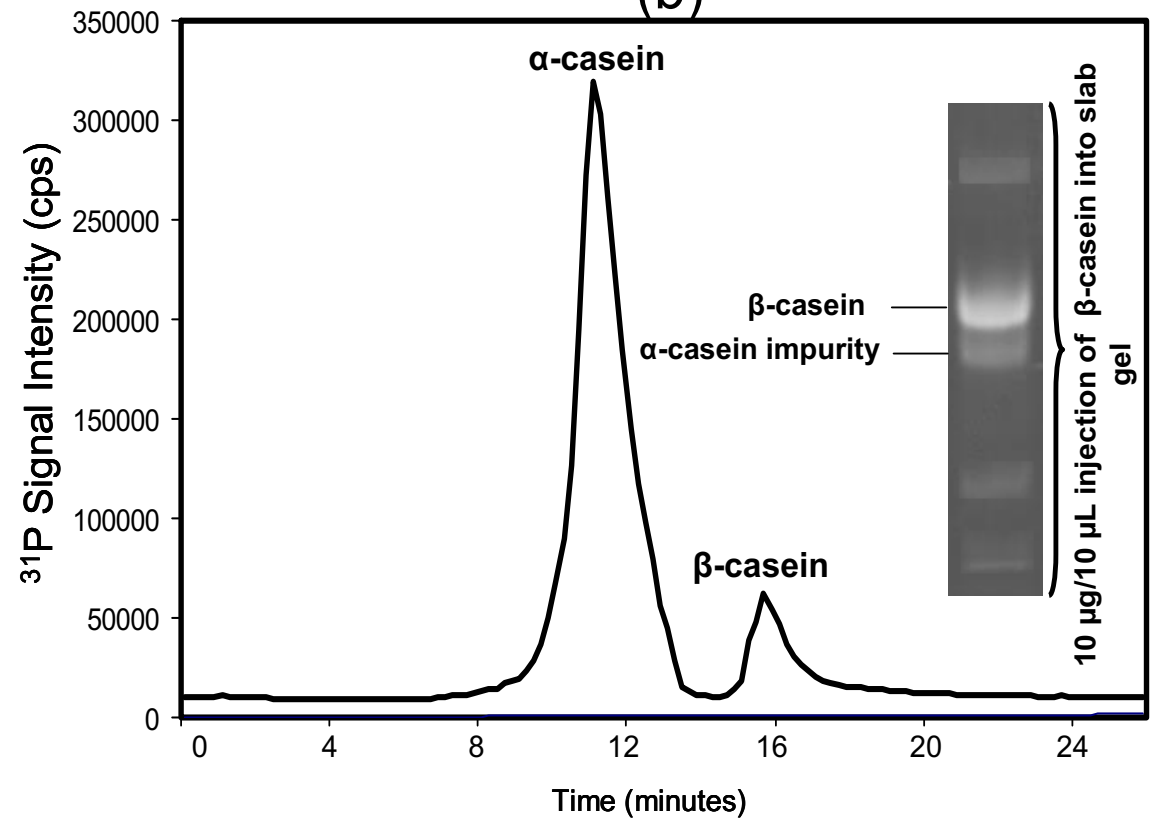


Fig. 4

(a)

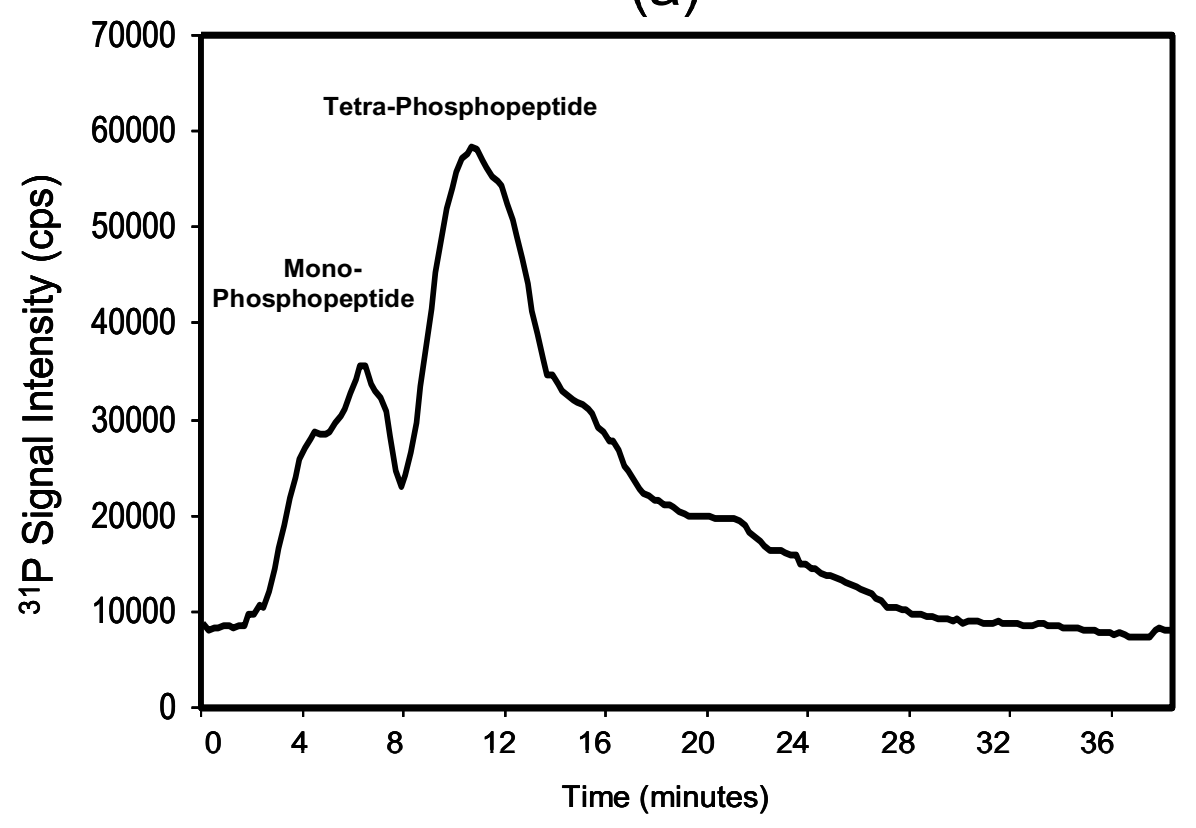

(b)

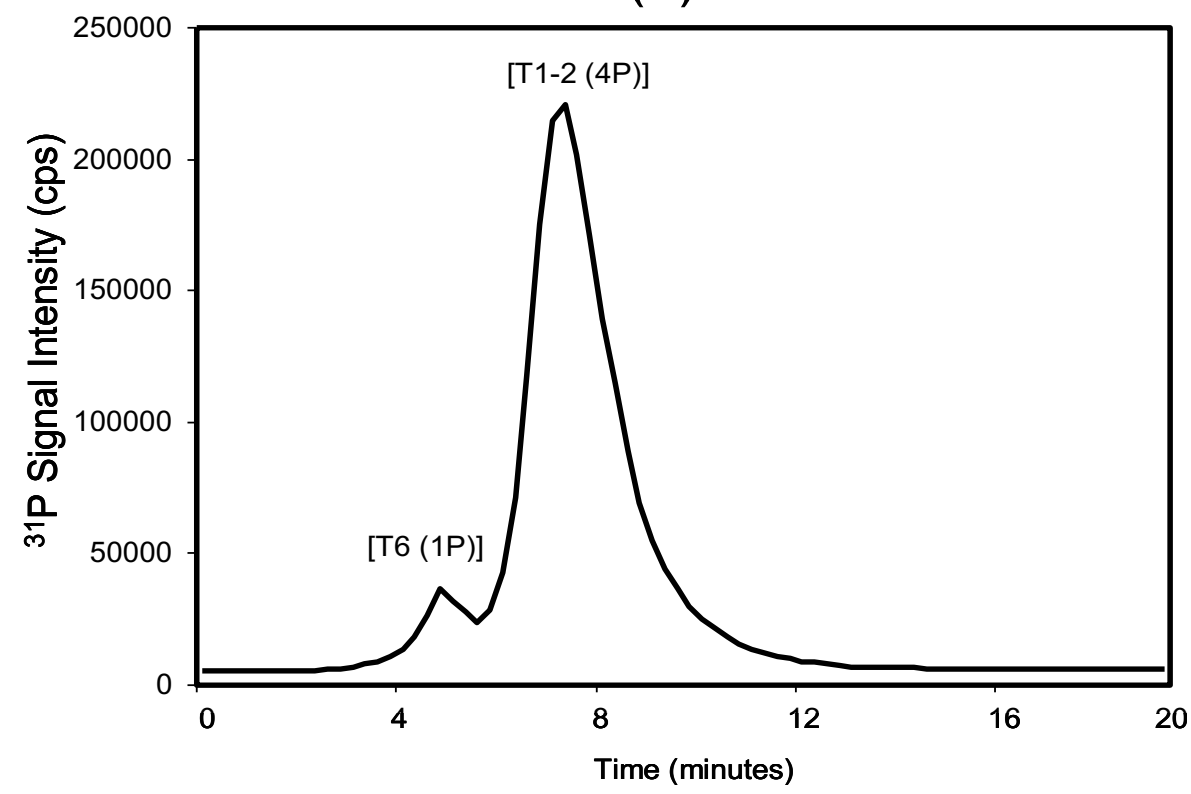


Fig. 5

(a)

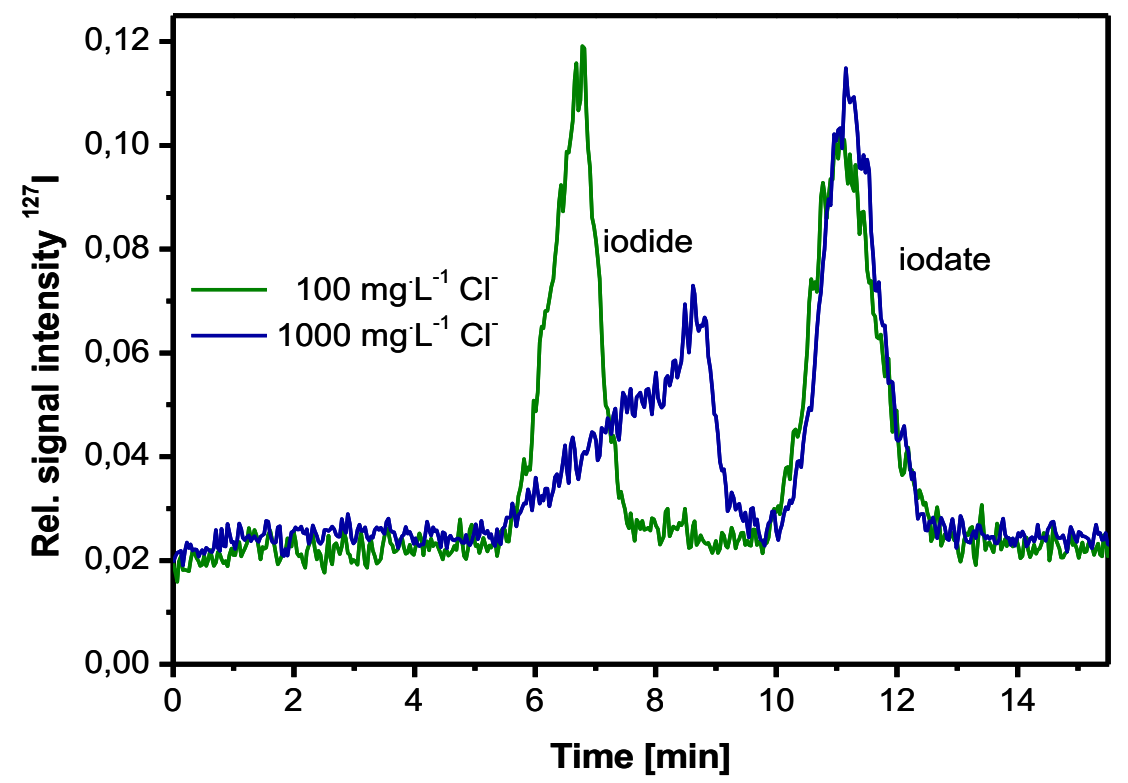

(b)

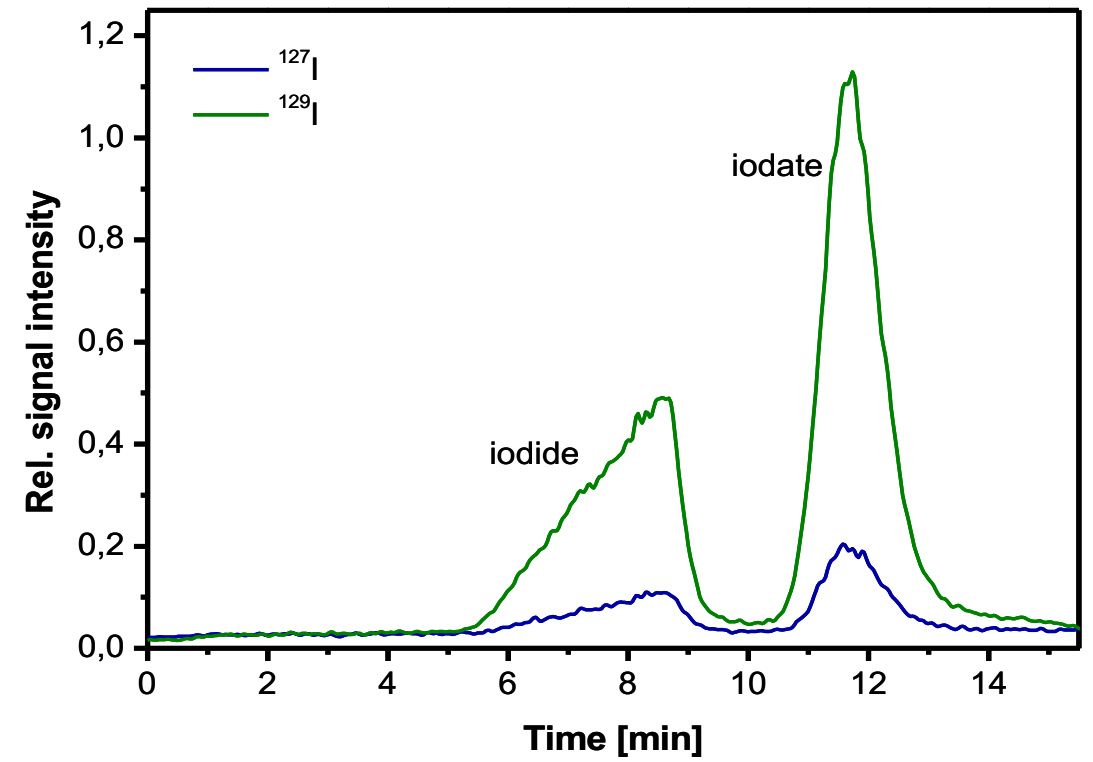


Fig. 6

(a)

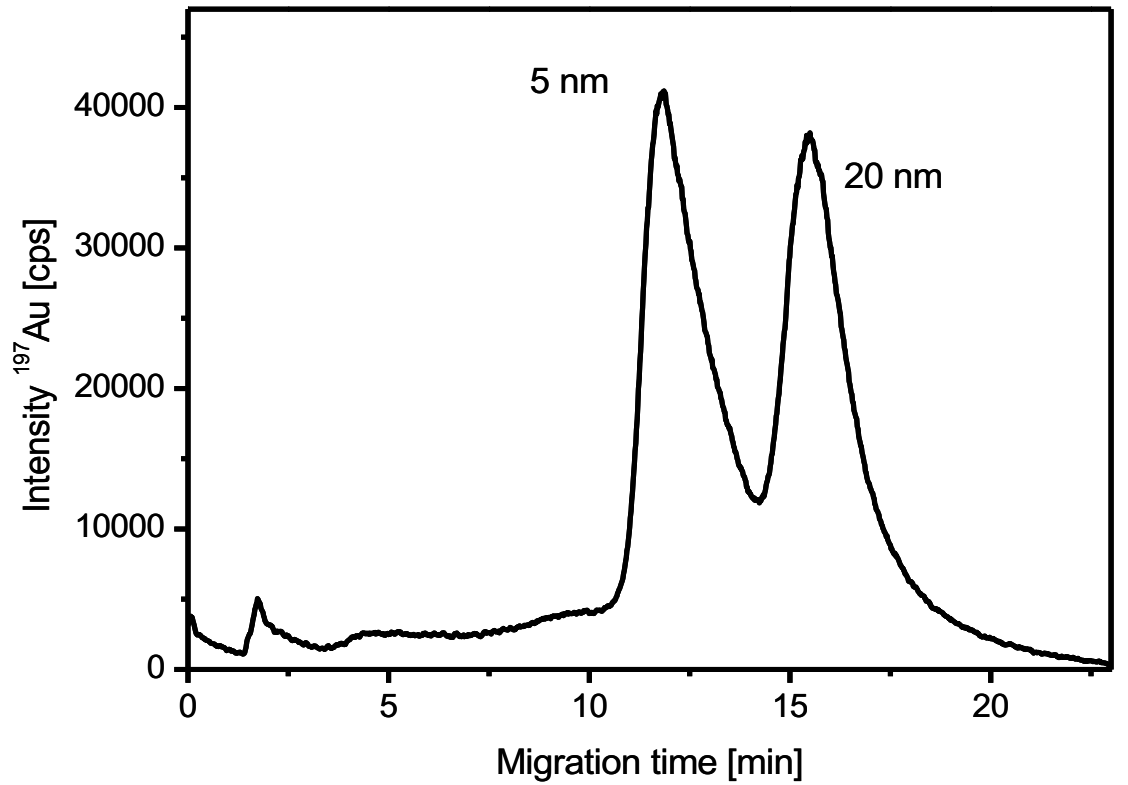

(b)

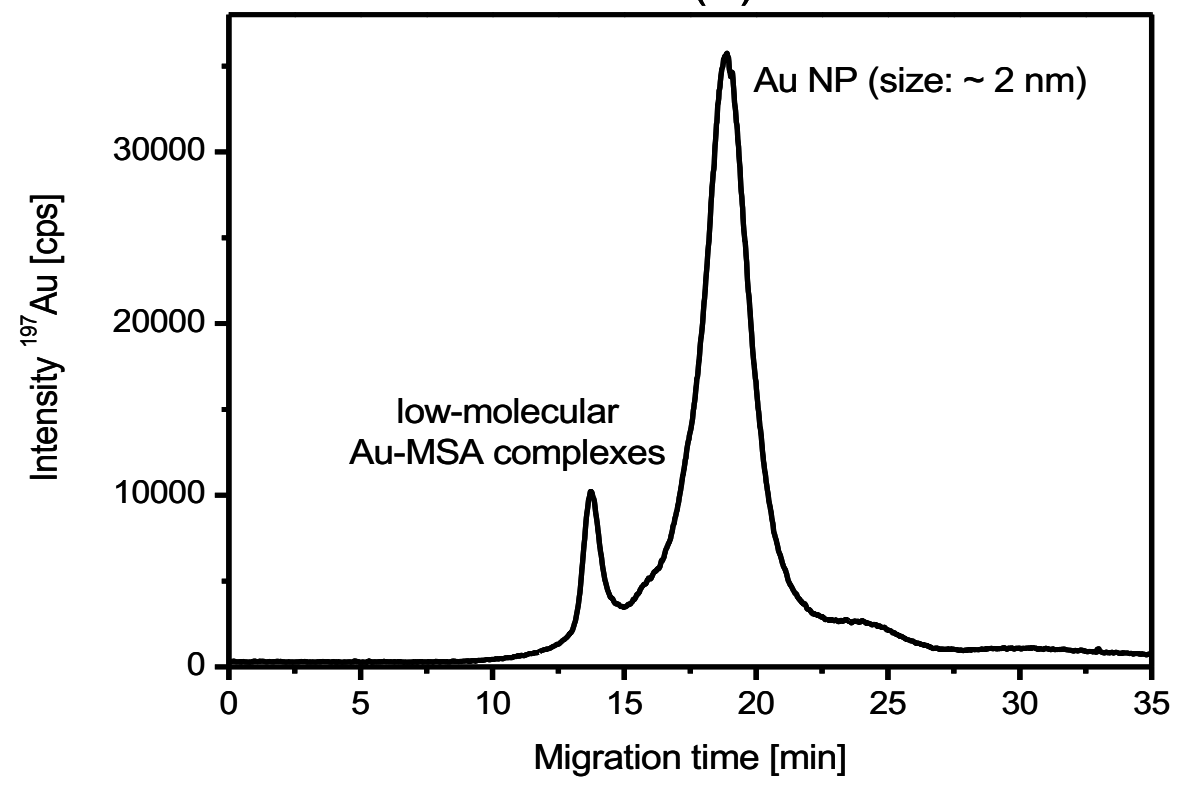


Fig. 7

(a)

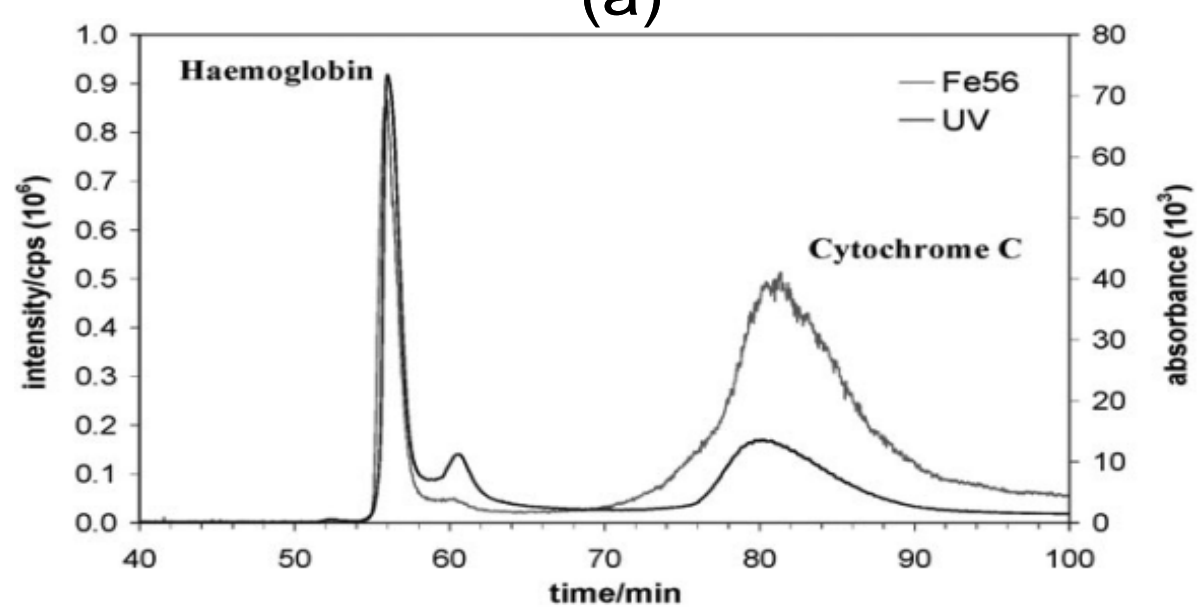

(b)

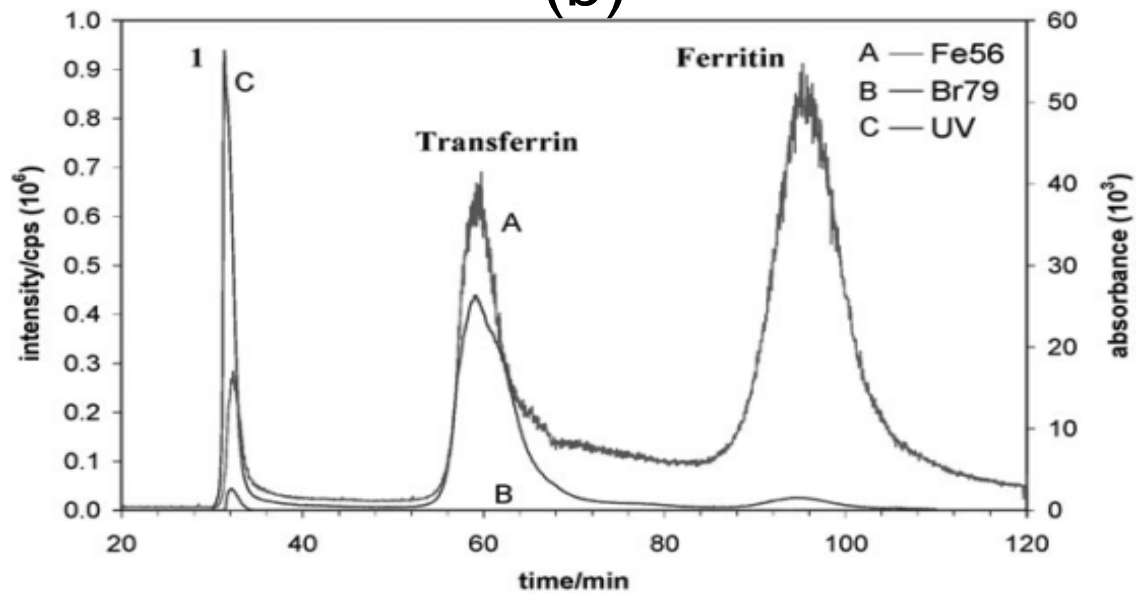

(c)

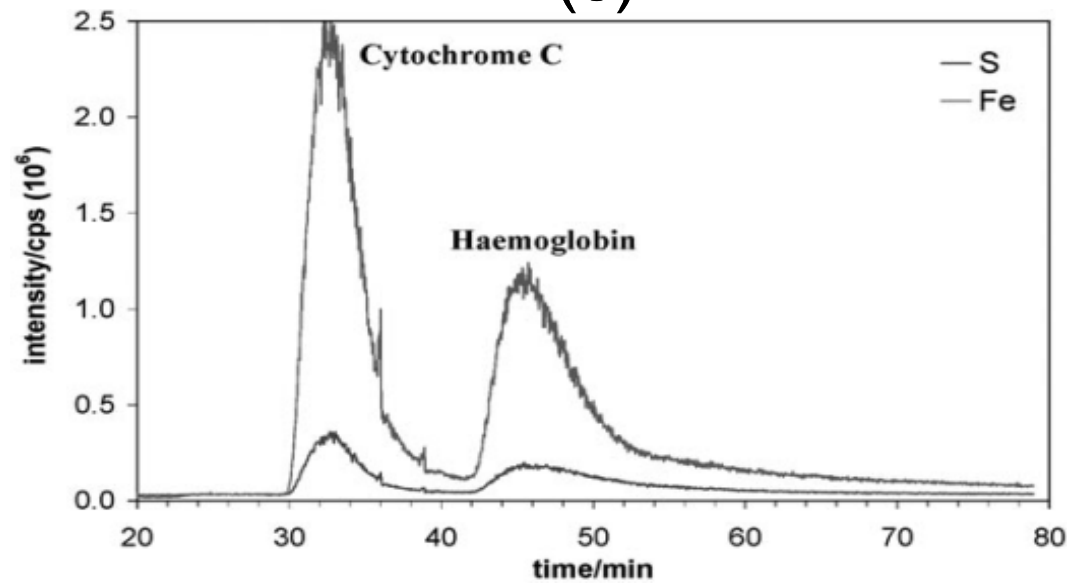


Fig. 8

(a)

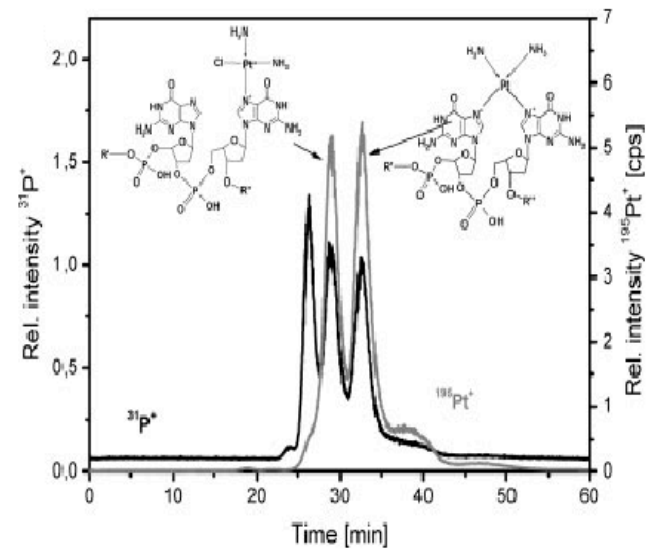

(b)

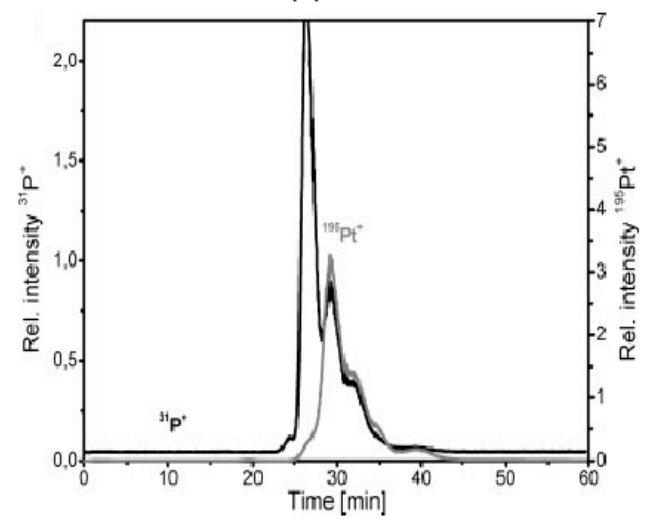

(c)

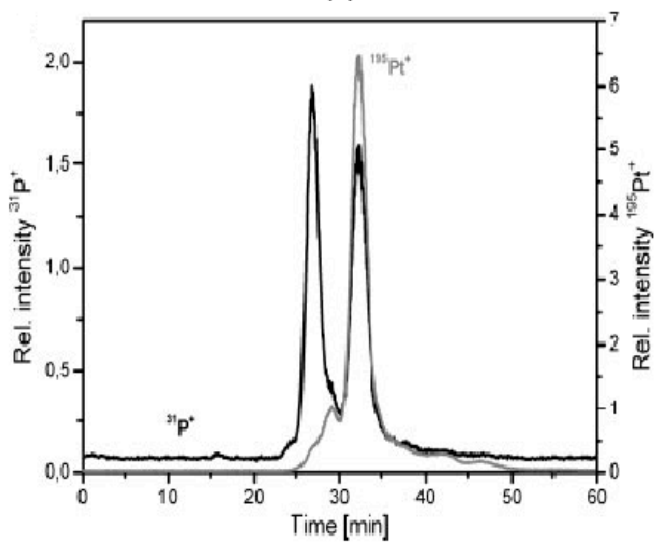

(d)

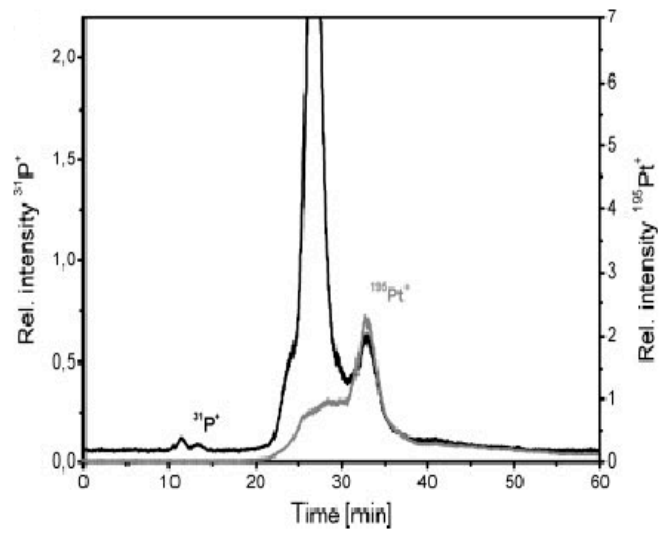


Fig. 9

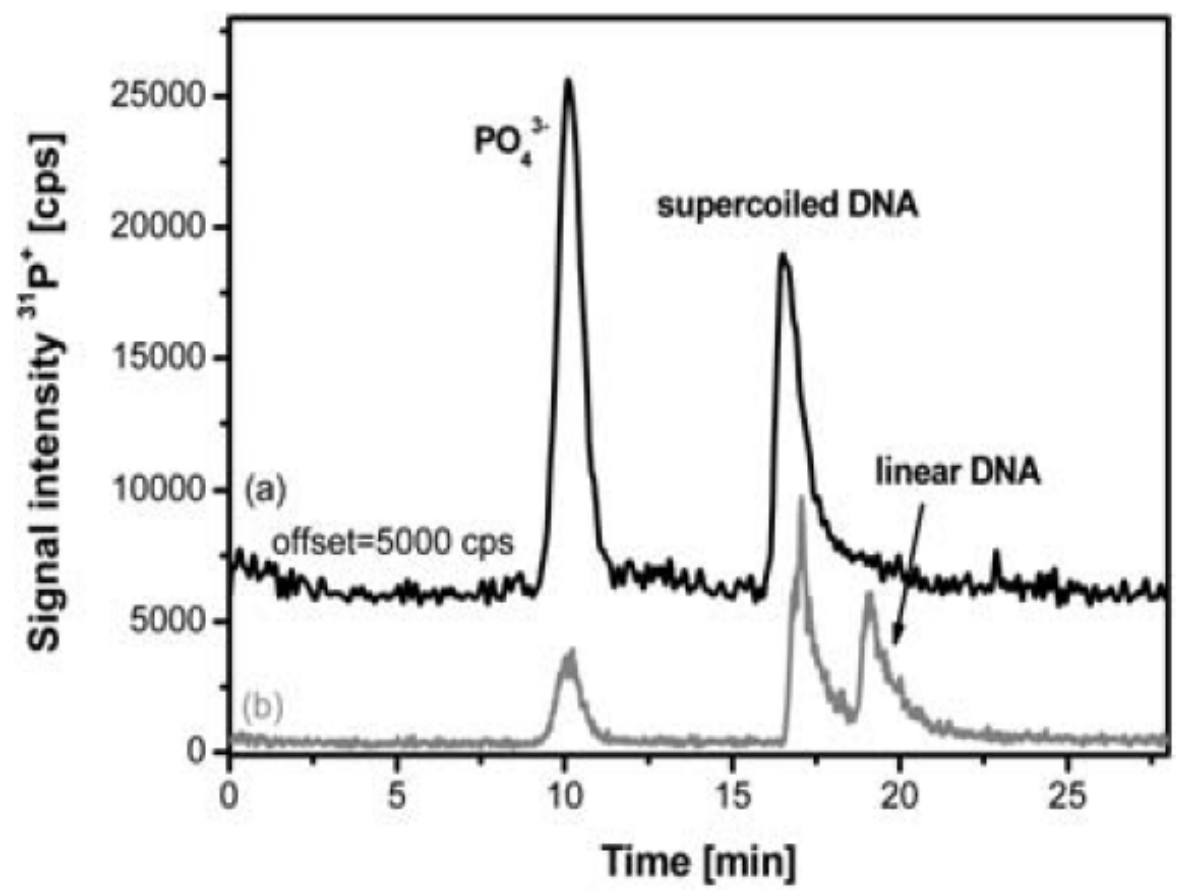




\section{Figure Captions}

Fig. 1 A typical instrumentation of GE-ICP-MS online system, (a) shows same buffer reservoir (b) different buffer reservoir for the elution of the analyte on ICP-MS. (Note: Dialysis membrane can be replaced by a plug gel in some cases).

Fig. 2 Electropherogram of the separation of the DNA base pairs using 1.8\% agarose gel at voltage of (a) $250 \mathrm{~V}$ and (b) $300 \mathrm{~V}$ [13]. () 2005 American Chemical Society with permission.

Fig. 3 A comparison of the separation of $\alpha$ - and $\beta$-casein: (a) 10 pmol $\alpha$ casein and $55 \mathrm{pmol} \beta$-casein in a $5 \%$ agarose gel (injection volume $3 \mu \mathrm{L}$ ) and (b) $1 \mathrm{fmol} \alpha$-casein and $1 \mathrm{fmol} \beta$-casein in a $10 \%$ polyacrylamide gel (injection volume $10 \mu \mathrm{L})$. In (b), $\alpha$-casein and other impurities present in $\beta$-casein decrease the signal intensity of the $\beta$-casein $[16,18]$. @ 2007 Royal Society of Chemistry and 2010 Springer-Verlag, with permission.

Fig. 4 Electropherogram for the $\beta$-casein digest. (a) GE-ICP-MS separation of mono and tetra-phosphopeptides from $\beta$-casein digest (b) GE-ICP-MS separation of mono and tetra-phosphopeptide standards [18]. (C) 2010 Springer-Verlag, with permission.

Fig. 5 GE-ICP-MS for (a) separation of $\mathrm{I}^{-}$and $\mathrm{IO}_{3}^{-}$(each $10 \mu \mathrm{g} \mathrm{L}^{-1}$ as I) in different matrices, (b) $\mathrm{I}^{129}$ enriched $\mathrm{I}^{-}$and $\mathrm{IO}_{3}^{-}$(each $100 \mathrm{\mu g} \mathrm{L}^{-1}$ as I) in 1000 $\mathrm{mg} \mathrm{L}^{-1} \mathrm{Cl}^{-}$[17] . () 2007 American Chemical Society, with Permission.

Fig. 6 GE-ICP-MS separation of gold nano-particles (a) gold nano-particles standards (b) gold nano-particles with MSA [14]. @ 2006 Royal Society of Chemistry, with Permission. 
Fig. 7 Electropherogram for the detection of ${ }^{56} \mathrm{Fe}$ (a) SDS-PAGE separation of haemoglobin and cytochrome $\mathrm{C}$. Parallel detection of ${ }^{56} \mathrm{Fe}$ and UV signal (wavelength $=280 \mathrm{~nm}$ ), (b) transferrin and ferritin separation by anodal native PAGE and (c) cytochrome $C$ and haemoglobin by cathodal native PAGE (parallel detection of Fe and S) [15]. @ 2007 Royal Society of Chemistry, with permission.

Fig. 8 GE-ICP-MS detection of ${ }^{31} \mathrm{P}$ and ${ }^{195} \mathrm{Pt}$ after $3 \mathrm{~h}$ and $24 \mathrm{~h}$ incubation of oligonucleotides with cisplatin. (a) and (c) show electropherogram for 5'TCCGGTCC-3' and (b) and (d) for 5'-TCCTGTCC-3' for $3 \mathrm{~h}$ and $24 \mathrm{~h}$ incubation respectively [19]. @ 2008 Wiley-VCH, with permission.

Fig. 9 GE-ICP-MS separation of the plasmid DNA (a) before and (b) after the enzymatic (BamHI) addition [20]. @ 2011 Royal Society of Chemistry, with permission. 